www.jmscr.igmpublication.org

Impact Factor 5.244

Index Copernicus Value: 83.27

ISSN (e)-2347-176x ISSN (p) 2455-0450

crossref DOI:_http://dx.doi.org/10.18535/jmscr/v4i9.91

\author{
Journal Of Medical Science And Clinical Research \\ IGM Publication \\ An Official Publication of IGM Publication
}

\title{
Endoscopic Dacryocystorhinostomy with and Without Silicone Stent: A Comparative Study
}

\author{
Authors \\ Dr Smitha.S.G ${ }^{1}$, Dr Jagannath.B ${ }^{2}$, Dr Shazia ${ }^{3}$ \\ ${ }^{1}$ Assistant Professor, Dept of ENT, Kempegowda Institute Of Medical Sciences, K.R Road V.V Puram, \\ Bangalore- 560004 Karnataka India \\ Email: smitha_praveen@hotmail.com, Contact No: +919901904836 \\ ${ }^{2}$ Associate Professor Dept of ENT, Kempegowda Institute Of Medical Sciences, K.R Road V.V Puram, \\ Bangalore- 560004 Karnataka India \\ Email: jashmidr12@gmail.com, Contact No: +919448081088 \\ ${ }^{2}$ Junior Resident, Dept of ENT, Kempegowda Institute Of Medical Sciences, K.R Road V.V Puram, \\ Bangalore- 560004 Karnataka India \\ Email: shazia.darkangel@gmail.com, Contact No: +917022140188
}

\begin{abstract}
Objectives: To assess and compare the surgical outcome of Endoscopic Endonasal Dacryocystorhinostomy (DCR) with stent and without stent. Surgical success was evaluated both subjectively as well as objectively.

Materials and Methods: 60 adults aged 18-60 years, with chronic epiphora were included in a prospective comparative study and categorized randomly into 2 groups that is DCR with stent / Group A and DCR without stent/Group B.

Results: Surgical outcome result was similar in both the groups. Furthermore the use of stent was found to be associated with granulation tissue formation, patient discomfort and increased risk of complications.

Conclusion: DCR with stent is associated with persistent complications and discomfort. It is therefore recommend that endoscopic DCR without silicone stent as the treatment of choice in cases of chronic dacryocystitis.
\end{abstract}

\section{INTRODUCTION}

With the introduction of high resolution endoscopes, endoscopic endonasal dacryocystorhinostomy (DCR) has begun to gain popularity ${ }^{1}$. Endoscopic DCR is proposed to be an alternative surgery to the external DCR operation in cases of chronic dacryocystitis ${ }^{1}$ Endoscopic DCR is a commonly performed operation in which a fistulous tract is created between the lacrimal sac and the nasal cavity in order to relieve epiphora due to nasolacrimal duct obstruction. Closure of the rhinostomy opening was considered a major factor for surgical failure in external $\mathrm{DCR}^{1,2}$. In external DCR, several methods such as use of silicone stent, application of Mitomycin-C to the rhinostomy opening and suturing of the mucosal flaps have been suggested for providing a permanent rhinostomy opening after completion of mucosal healing ${ }^{2}$. However, in endonasal DCR insertion of silicone stent is the most commonly preferred procedure ${ }^{2}$. It has been claimed that silicone stent improves surgical outcomes of endoscopic $\mathrm{DCR}^{2}$, by maintaining the patency of the fistula during the post operative healing period. On the other hand, 
some studies indicate that silicone stent itself is a reason of surgical failure due to granulation tissue formation and complications like punctual erosion and slitting of canaliculi ${ }^{2,3,5}$.

The present study was therefore undertaken with the aims to evaluate placement and to compare the results of endoscopic DCR with and without the use of silicone stent.

\section{MATERIALS AND METHODS}

A propective comparative study was conducted at the Department of ENT, Kempegowda Institute of Medical sciences, Bangalore from June 2012 to January 2015.

60 consenting adults of both sexes aged 18- 60 years with symptoms and signs suggestive of chronic dacrocystitis due to nasolacrimal duct obstruction, undergoing endoscopic endonasal DCR were included in the study. Patients having chronic sinusitis, nasal polyps, deviated nasal septum on same side and severe bony deformity of lacrimal sac fossa (post-traumatic), and other ophthalmic conditions were excluded from the study.

The patients were randomized into two groups, A, and B with 30 patients each. Patients in group A underwent endoscopic DCR with silicone stent placement while those in group B underwent endoscopic DCR without stent. Initial patient workup included detailed history followed by general and ENT examination including complete ophthalmologic examination, diagnostic nasal endoscopy examination and lacrimal duct syringing. A dacrocystogram was obtained for all patients, followed by routine pre operative investigations and evaluation. Endoscopic endonasal DCR was performed in all patients. The Crawford lacrimal silicone stent was placed in group A patients. Post operative care included a regime of oral antibiotics and anti inflammatory drugs, nasal decongestant, steroid nasal spray and local antibiotic eye drops. All patients were discharged on the $2^{\text {nd }}$ post operative day.

Regular follow-up of patients was done at 1, 2, 6 and 10 weeks and at 6 months. In group A patients, the silicone stent was removed in $6^{\text {th }}$ postoperative week. On all visits subjective assessment for symptomatic improvement was done, which was defined as the presence or absence of epiphora.

Objective anatomical success was defined as patency on syringing \& presence of a functioning rhinostomy, which was, evaluated using the functional endoscopic dye test and classified as patent, partially patent and blocked.

\section{STATISTICAL ANALYSIS}

Data tabulation and analysis using tests such as unpaired $\mathrm{t}$ test for the parametric data and Chi square test and Mann Whitney $U$ test for non parametric data, along with other statistical tests will be applied based on the need, based on these to draw appropriate conclusions and table recommendations merited.

\section{RESULT}

The age of patients in the study ranged from 25-60 years with the most common age group affected being 25-30 years with a mean age of $33.8 \pm 2.53$ years. (41\%) female and (59\%) male met the inclusion criteria of which Male: Female ratio in group $\mathrm{A}$ and $\mathrm{B}$ are 1:1 and 2:1 ratio respectively.

All patients presented with epiphora. Additional symptoms noted were discharge from the eye in $80 \%$ patients in group A and $85 \%$ in group B and swelling over the lacrimal sac area in $10 \%$ of patients in both groups. The mean duration of symptoms was found to be $18 \pm 1.28$ months in group $\mathrm{A}$ and $17 \pm 1.65$ months in group B. Intraoperatively, mucoid discharge, mucopurulent discharge, purulent discharge, hypertrophic lacrimal sac, atrophic sac was seen in 33\%, 16\%,3\%, 10\%, $0 \%$ of group A patients respectively and $23 \%, 13 \%$, $6 \%, 3 \%, 0 \%$ respectively in group B category. On follow up complications such as post operative bleeding was seen in $16 \%$ of group A, and $26 \%$ of group B patients, difficulty in removal of stent was seen in16\%, spontaneous expulsion of stent was seen in $16 \%$ of group A patients. Rhinostomy closure due to granulation formation was found in $13 \%$ of group B patients. 
Table: 1 Subjective Outcome Assessment

\begin{tabular}{|c|c|c|c|c|c|c|c|c|c|c|}
\hline DISEASE CATEGORY & \multicolumn{2}{|c|}{1 WEEK } & \multicolumn{2}{|c|}{2 WEEKS } & \multicolumn{2}{|c|}{6 WEEKS } & \multicolumn{2}{|c|}{10 WEEKS } & \multicolumn{2}{|c|}{6 MONTHS } \\
\hline & Grp A & Grp B & Grp A & Grp B & Grp A & Grp B & Grp A & Grp B & Grp A & Grp B \\
\hline $\begin{array}{l}\text { No: of patients with } \\
\text { syringing patent }\end{array}$ & 20 & 25 & 20 & 25 & 25 & 28 & 28 & 29 & 29 & 30 \\
\hline $\begin{array}{l}\text { No:of patients with } \\
\text { syringing partially patent }\end{array}$ & 6 & 5 & 6 & 5 & 4 & 2 & 2 & 1 & 1 & 0 \\
\hline $\begin{array}{lll}\begin{array}{l}\text { No:of } \\
\text { blocked }\end{array} & \text { syringing } & \text { with } \\
\end{array}$ & 4 & 0 & 4 & 0 & 1 & 0 & 0 & 0 & 0 & 0 \\
\hline
\end{tabular}

Table 2: Objective Assessment Of Full Surgery

\begin{tabular}{|l|l|l|l|l|l|l|l|l|l|l|l|l|}
\hline DISEASE CATEGORY & 1 WEEK & 2 WEEKS & 6 WEEKS & \multicolumn{2}{l|}{10 WEEKS } & \multicolumn{2}{l|}{ MONTHS } \\
\hline & Grp A & Grp B & Grp A & Grp B & Grp A & Grp B & Grp A & Grp B & Grp A & Grp B \\
\hline $\begin{array}{l}\text { No: of patients with syringing } \\
\text { patent }\end{array}$ & 0 & 22 & 0 & 22 & 25 & 25 & 27 & 29 & 29 & 30 \\
$\begin{array}{l}\text { No:of patients with syringing } \\
\text { partially patent }\end{array}$ & 0 & 0 & 0 & 0 & 3 & 4 & 2 & 1 & 1 & 0 \\
\hline No:of syringing with blocked & 0 & 0 & 0 & 0 & 1 & 0 & 1 & 0 & 0 & 0 \\
\hline
\end{tabular}

\section{DISCUSSION}

In our study, complete relief from symptoms was seen in $85 \%$ of patients with stent and $90 \%$ of patients without stent. However rhinostomy obstruction secondary to granulation formation was observed in $13 \%$ of patients in the non stent group. Jin reported primary success rate of $83 \%$ with endoscopic DCR with stent and in $17 \%$ cases rhinostomy opening was found to be obstructed by granulation or synechie. Sprekelson reported success with endoscopic DCR with stent in $85 \%$ patients. The success rate of endoscopic DCR without stent reported in other literature varies from $85 \%$ to $98 \%$ which is comparable to our study ${ }^{4}$. Singh $^{5}$ reported success rate of $92.6 \%$ of endoscopic DCR without stent and $\mathrm{Unlu}^{7}$ reported $90.5 \%$ of success with no major complication, as was observed in our study. Similarly, Kakar et.al recommend endoscopic DCR without silicone stent as the treatment of choice in cases of chronic dacryocystitis

Kims et al reported decrease long term patency with stents with a success rates dropping from $90 \%$ to $70 \%{ }^{11}$. Also a major factor affecting patency after removal of stent removal was contraction of lacrimal sac at the time of stent removal ${ }^{11}$.

Naik et.al concluded that the surgical success rate of Endoscopic DSR with stent is equal to that without stent ${ }^{9}$. Minimal patient discomfort and complications were seen in patients with stent ${ }^{9}$. In contrast Durvasula reported good results with use of stent after 3 months ${ }^{10}$.

Similarly, in our study, no significant difference in improvement or complications was observed between both stent and non stent groups indicating no significant advantage in using stents routinely in Endo DCR.

Singh et $\mathrm{al}^{5}$ and Sham et ${ }^{6}$ al on the basis of their studies opined that silicone stenting is not routinely indicated in endoscopic DCR. Moreover, silicone stent is associated with high failure rate due to granulomatous inflammation and complications as punctal erosion and slitting of canaliculi. Other complications include postoperative discomfort, corneal abrasion and canaliculi erosion form stent. Jin reported bleeding from nasal cavity, orbital injury, CSF leakage through fractured ethmoid, corneal abrasion, canaliculi erosion due to overly tight silicone tube placement and lacrimal pump syndrome associated with use of stent ${ }^{6}$. however no such complications were noted in our study.

\section{CONCLUSION}

In conclusion, considering that the surgical results of endonasal DCR with or without stent are almost equal and the use of stent is associated with patient 
discomfort, increased risk of complications and additional cost, we recommend that endonasal DCR without silicone stent be the treatment of choice for chronic dacryocystitis.

\section{REFERENCES}

1. Rice DH. Endoscopic intranasal dacryocystorhinostomy results in four patients. Arch Otolaryngol Head Neck Surg 1990; 116(6): 1061.

2. Onerci M, Orhan M, Ogretmenoglu O, Iruec M. Long term results and reasons for failure of intranasal endoscopic dacryocystorhinostomy. Acta Otolaryngol 2000; 120: 319-22.

3. Jin HR, Yeon JY, Choi MY. Endoscopic dacryocystorhinostomy: Creation of a large marsupialized lacrimal sac. J Korean Med Sci 2006; 21: 719-23.

4. Sprekelson MB. Endoscopic dacryocystorhinostomy- surgical techniques and results. Laryngoscope 1996; 106: 187-9.

5. Singh M, Jain V, Gupta SC, Singh SP. Intranasal endoscopic DCR (END-DCR) in cases of dacryocystitis. Ind J Otolargngology Head Neck Surg 2004; 56(3): 177-83.

6. Sham CL, van Hasselt CA. Endoscopic terminal dacryocystorhinostomy. Laryngoscope 2000; 110: 1045-9.

7. Unlu, H. H., Aslan, A., Toprak, B., \& Guler, C. (2002). Comparison of surgical outcomes in primary endoscopic dacryocystorhinostomy with and without silicone intubation. Annals of Otology, Rhinology \& Laryngology, 111(8), 704-709.

8. Kakar, V., Chugh, J. P., Sachdeva, S., \& Sharma, N. (2009). Ramesh. Endoscopic dacryocystorhinostomy with and without silicone stent: A comparative study. Internet J Otorhinolaryngol, 9, 1.

9. Naik, S. M., Mushannavar, A. S., Ravishankara, S., Appaji, M. K., Goutham, M. K., Devi, N. P., \& Naik, S. S. (2012). Endonasal Dacryocystorhinostomy done with and without Silicon Tube Stents: A Comparative Case Series Analysis Study. Head Neck Surg, 3(3), 147-153.
10. Durvasula, V. S. P, Gatland, D. J. (2004). Endoscopic dacrocystorhinostomy: longterm results and evolution of surgical technique. The Journal of Laryngology \& Otology, 118(08), 628-632.

11. Kims JH, Shin JH, Song, et al. Long term results and fact Vas. Interv Radiol 2006;17(7): 1125- 36. 